\title{
Identify Work from Home Priorities Using an Analytical Hierarchy Process
}

\author{
Nita Nurliawati ${ }^{1}$, Gugun Geusan Akbar $^{2}$ \\ \{nitanurliawati@yahoo.com¹; gugun.ga@fisip.uniga.ac.id $\left.{ }^{2}\right\}$ \\ ${ }^{1}$ Polytechnic of STIA LAN Bandung \\ ${ }^{2}$ University of Garut
}

\begin{abstract}
This study aims to understand the critical factors for the success of work from home policies for civil servants so that they can be considered for similar policies in the future. This study uses a literature review, opinions of employees who have implemented work from home, and an analytical hierarchy process methodology to identify and prioritize important factors in work from home for civil servants to find the most effective strategy. Employees who have implemented work from home are asked to prioritize five main criteria (efficiency, environment, productivity, flexibility, and satisfaction) and 15second criteria. The results showed that satisfaction had the highest priority $(0.400)$, followed by environmental factors (0.249), efficiency (0.131), flexibility $(0.119)$, and productivity (0.102). These findings can help the government design appropriate steps to design work from home policies in the future. This study identifies the importance of including employees who have implemented work from home in creating work from home policies.
\end{abstract}

Keywords: Work From Home; Government employees; Analytic Hierarchy Process

\section{Introduction}

The presence of Covid-19 at this time has caused changes to the activities of communities, corporate organizations, and governments around the world and has led to an adaptation process in conditions that are all emergency and sudden. Not only that, but Covid-19 also has a severe impact on all aspects of life such as the economy [1], business [2], investment [3], traveling [4], social [5], quality of life [6] as well as in education [7]. In Indonesia, the rapid spread of Covid19 has prompted the government to issue various policies to break the chain of transmission of Covid-19. During the Covid-19 pandemic, the government urges that multiple activities such as implementing learning and work be carried out from home or popularly known as work from home (WFH).

On March 16, 2020, the Ministry of State Apparatus Empowerment and Bureaucratic Reform issued a policy to control the spread of COVID-19 in the community. The regulation instructs the public during the COVID-19 outbreak to stay at home or work from home [8]. All employees are encouraged to work from home except those who must be in the office for very urgent reasons.

Requiring employees to work from home suddenly is a difficult decision considering the effectiveness of working from home has not been good [9], [10]. In addition, the obstacle in the 
policy of working from home is that there are still $36 \%$ of Indonesians who have not been able to take advantage of technology [11]. Another barrier is that more than half of employees recognize that developing collaboration with coworkers while working from home is tough because they have trouble separating business and personal life. [12].

Remote working or working from home is a term to describe the act of performing one's core professional activity away from the company's core professional location. There have been many concepts about working from home or working remotely that have been put forward by experts, including variables or factors related to working remotely.

Table 1 provides an overview of the various variables associated with working remotely.

Table 1. Variable review of working from home

\begin{tabular}{lll}
\hline \multicolumn{1}{c}{ Variable } & \multicolumn{1}{c}{ Factor } & \multicolumn{1}{c}{ Author } \\
\hline Efficiency & Cost-saving & Gage, 1998; Schilling, 1999 \\
& Traveling cost & Fortier, 1998 \\
Environment & Environment issues & Kurland and Bailey, 1999; \\
& Conducive environment & Kurland and Bailey, 1999; \\
& & Ervin, 1998; \\
Productivity & Work Productivity & Sullivan, 1992; Kurland and \\
& & Bailey, 1999; \\
& & Sullivan, 1992 \\
Flexibility & Job Flexibility & Kurland and Bailey, 1999; \\
& & Fortier, 1998 \\
Satisfaction & Job Satisfaction & Kurland and Bailey, 1999 \\
\hline
\end{tabular}

Source: processed from various sources

When viewed from the factors related to work from home above, which are pretty complex, it is necessary to analyze all elements of work from home in an integrated approach to carry out effectively. Therefore, it is needed to determine which issues should be prioritized for consideration and planning. In the period of working from home policy in Indonesia, many studies have been conducted to try to capture emerging phenomena from various perspectives, for example, information technology [13], health [14], gender [15], government policy [16], psychology [17], economy [18] education [19], and various perspectives and methods. However, research that analyzes the elements of work from home and determines the priorities of these elements has not been carried out.

The purpose of this study is to identify the factors that influence the implementation of work from home for civil servants and prioritize the elements that have been selected based on a literature study using survey data and the AHP methodology. In particular, we ensure the most important elements in the effective implementation of work from home from employees who already have work from home experience with the ultimate goal of increasing the effectiveness of the implementation of work from home.

\section{Methods}

The AHP technique is used in this study to prioritize elements that influence the deployment of Work From Home by Indonesian civil officials. The AHP approach can reflect the decision-making process's multi-layered structure, and it's commonly employed for analysis in unexpected situations that require several assessment criteria. The AHP approach is utilized in research that necessitates many understandings. Saaty [20] created AHP, which is a versatile 
method for analyzing multi-criteria situations by creating a hierarchy for decision making through priority setting [21].

Object creation, selection of evaluation criteria, expert evaluation, validation, and determination of values that are weighed for various parts in the Work From Home implementation process are all part of the AHP process. A pairwise comparison matrix with adjoining technical and normative models for interpretation makes up the scoring criteria for AHP. The data for AHP from this study comes from expert opinion [22], [23], [24], [25], to determine Criterion 1 and Criterion 2 and interviews with employees who carry out work from home to determine priorities. Based on the literature review, table 2 shows the elements of implementing Work From Home in two levels, criteria one and two.

Criterion 1 consists of efficiency, environment, productivity, flexibility, and satisfaction. Criterion 1 is then further classified into three categories of criteria 2. The efficiency criteria factors consist of saving time, saving costs, avoiding traffic jams. Environmental criteria factors consist of a conducive environment, safe environment, unnecessary interaction. The productivity criteria factors consist of increasing productivity, developing skills, increasing independence. Flexibility criteria factors consist of the flexibility of place, the flexibility of time, and the flexibility of arrangement. Finally, the satisfaction criteria factors consist of physical satisfaction, physiological satisfaction, and spiritual satisfaction.

Data collection was carried out for two weeks, between August 1-15, 2021. In total, 52 people were involved in the interviews by filling out a questionnaire. The resource persons were employees in government institutions who carried out work from home. The resource persons come from government organizations that have experience in implementing work from home. Table 3 shows a summary of the respondent's age, knowledge, and experience.

Table 2. Evaluation of Criteria in the Implementation of Work From Home

\begin{tabular}{cll}
\hline \multicolumn{1}{c}{ Variable } & \multicolumn{1}{c}{ Factor } & \multicolumn{1}{c}{ Author } \\
\hline Efficiency & Cost-saving & Gage, 1998; Schilling, 1999 \\
& Traveling cost & Fortier, 1998 \\
Environment & Environment issues & Kurland and Bailey, 1999; \\
& Conducive environment & Kurland and Bailey, 1999; Ervin, 1998; \\
Productivity & Work Productivity & $\begin{array}{l}\text { Sullivan, 1992; Kurland and Bailey, 1999; } \\
\text { Sullivan, 1992 }\end{array}$ \\
& & Kurland and Bailey, 1999; Fortier, 1998 \\
Flexibility & Job Flexibility & Kurland and Bailey, 1999 \\
Satisfaction & Job Satisfaction & \\
\hline
\end{tabular}

The demographic characteristics of the respondents can seen in table 3 below

Tabel 3. Interviewees' Demographic Characteristics

\begin{tabular}{llll}
\hline Category & & No of Responden & Percentage \\
\hline Total & & 52 & 100 \\
Sex & Male & 26 & 50 \\
& Female & 26 & 50 \\
Age & 20 & 12 & 23 \\
& 30 & 15 & 29 \\
& 40 & 16 & 31 \\
Education & 50 & 9 & 17 \\
& D1/D2/D3 & 3 & 6 \\
& D4/S1 & 20 & 38 \\
& $\mathrm{~S} 2$ & 23 & 44 \\
Experience & S3 & 6 & 12 \\
& $0-10$ years & 18 & 35 \\
& $11-20$ years & 22 & 42
\end{tabular}




$\begin{array}{llll} & 21-30 \text { years } & 9 & 17 \\ & >30 \text { years } & 3 & 6 \\ \text { Distance } & 0-5 \mathrm{~km} & 15 & 29 \\ \text { from office } & 6-10 \mathrm{~km} & 13 & 25 \\ \text { to home } & 10-15 \mathrm{~km} & 10 & \\ & >15 \mathrm{~km} & 14 & 19 \\ & & & 27\end{array}$

The AHP was used to evaluate the items on Criteria 1 and 2 based on pairwise comparisons. There are a total of 5 and 15 evaluations for Criterion 1 and 2 questions, respectively. As stated in Table 4, the evaluation measure is a 9-point scale that is commonly used [26]. The submission of erroneous data by the interviewee can have a negative impact on the AHP pairwise comparison procedure. To circumvent this, the data was validated using the consistency ratio (CR). A CR value of less than 0.1 is generally regarded consistent, and a CR of $0.1-0.2$ is acceptable [3].

Only data with a CR of less than 0.2 were included in this analysis. Following data validation, results from pairwise comparisons were used to ensure that each criterion was consistent. After determining the relative relevance of each criterion, the geometric mean is used to indicate the respondent's opinion.

Tabel 4. Significance of the Pairwise Comparisons

\begin{tabular}{|c|c|c|}
\hline Scale & Definition & Description \\
\hline 1 & Equal & Two activities have equal contribution \\
\hline 3 & Weak & $\begin{array}{l}\text { One activity is mildly preferred over the other based on } \\
\text { experience and judgment }\end{array}$ \\
\hline 5 & Strong & $\begin{array}{l}\text { One activity is strongly preferred over the other based } \\
\text { on } \\
\text { experience and judgment }\end{array}$ \\
\hline 7 & Very Strong & $\begin{array}{l}\text { One activity is very strongly preferred over the other } \\
\text { based on } \\
\text { experience and judgment }\end{array}$ \\
\hline 9 & Extreme & $\begin{array}{l}\text { One activity is extremly preferred over the other based } \\
\text { on } \\
\text { experience and judgment }\end{array}$ \\
\hline $2,4,6,8$ & Median & $\begin{array}{l}\text { Median comparison value based on experience and } \\
\text { judgment }\end{array}$ \\
\hline
\end{tabular}

\section{Results and Discussion}

\subsection{Evaluation Criterion 1}

Figure 1 shows that when work is done at home, satisfaction $(0.400)$ is the most important criterion 1 . The environment $(0.249)$ is the second most important factor, followed by efficiency $(0.131)$, flexibility $(0.119)$, and productivity $(0.102)$. 

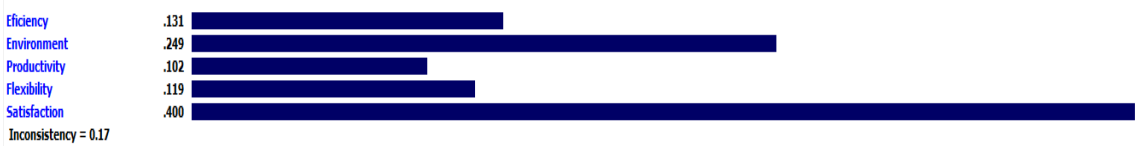

Fig 1. Evaluation of 1 criteria criteria based on survey data

These results indicate the level of reasonableness considering that employees work in situations filled with anxiety and full of uncertainty so that working from home creates satisfaction for employees. There was no difference in how male and female respondents ranked criteria 1. (Table 5). Female respondents, on the other hand, placed a greater emphasis on efficiency than male respondents. When it comes to working at home, satisfaction is the most essential factor for all age groups; nevertheless, respondents in their 20 s are also conscious of the relevance of environmental factors. Older respondents, on the other hand, place a higher value on satisfaction than other factors.

Judging from the level of education, respondents with a master's level of education think that the satisfaction aspect is the most important criterion 1, while based on work experience, respondents with 21 years of experience or more tend to have the opinion that the satisfaction aspect is the most important criterion 1 . This reflects the satisfaction that arises when working from home is considered more important than other aspects. The difference is also seen based on the distance from the office to the house. Respondents who are closer to the office to their home have a higher level of satisfaction than those farther away.

Table 5. Ranking of factors considered important in Criterion 1

\begin{tabular}{llllllll}
\hline Category & & no & Kepuasan & Lingkungan & Efisiensi & Fleksibilitas & Produktivitas \\
\hline Total & Laki-Laki & 52 & 0.400 & 0.249 & 0.131 & 0.119 & 0.102 \\
Sex & Perempuan & 26 & 0.312 & 0,275 & 0.151 & 0.115 & 0.105 \\
& 20 & 12 & 0.253 & 0,319 & 0.139 & 0.125 & 0.115 \\
Age & 30 & 15 & 0.310 & 0,259 & 0.155 & 0.115 & 0.115 \\
& 40 & 16 & 0.459 & 0,245 & 0.159 & 0.193 & 0.112 \\
& 50 & 9 & 0.445 & 0,212 & 0.119 & 0.19 & 0.116 \\
Education & D1/D2/D3 & 3 & 0.359 & 0,259 & 0.129 & 0.128 & 0.105 \\
& D4/S1 & 20 & 0.365 & 0,278 & 0.145 & 0.116 & 0.117 \\
& S2 & 23 & 0.378 & 0,248 & 0.133 & 0.157 & 0.101 \\
Experience & S3 & 6 & 0.348 & 0,275 & 0.122 & 0.117 & 0.110 \\
& 11- Tahun tahun & 18 & 0.295 & 0,234 & 0.138 & 0.115 & 0.106 \\
& $21-30$ tahun & 9 & 0.281 & 0,342 & 0.113 & 0.118 & 0.102 \\
& $>$ dari 30 & 3 & 0.458 & 0,312 & 0.143 & 0.105 & 0.111 \\
Distance & tahun & & & 0,231 & 0.123 & 0.119 & 0.120 \\
from office & 0-5 km & 15 & 0.256 & 0.225 & 0.157 & 0.117 & 0.105 \\
to home & 10 $10 \mathrm{~km}$ & 13 & 0.105 & 0.256 & 0.115 & 0.115 & 0.102 \\
& $>$ dari $15 \mathrm{~km}$ & 10 & 0.151 & 0.245 & 0.133 & 0.114 & 0.115 \\
& 14 & 0.121 & 0.191 & 0.129 & 0.112 & 0.108 \\
\hline
\end{tabular}

\subsection{Evaluation Criteria 2}

Of criterion 2 relating to aspects of satisfaction, spiritual satisfaction (0.43) is the most important criterion, followed by psychological satisfaction $(0.387)$ and physical satisfaction (0.169), as shown in Table 6. We attribute higher spiritual satisfaction to conditions during a pandemic that can be life-threatening, which is why respondents feel that spiritual satisfaction is more important when working at home during a pandemic. This is reinforced by higher psychological satisfaction than physical satisfaction.

Table 6. Evaluation of Satisfaction Criteria 


\begin{tabular}{llll}
\hline $\begin{array}{l}\text { Primary } \\
\text { Criteria }\end{array}$ & $\begin{array}{l}\text { Importance (Based on } \\
\text { Criteria 1 Evaluation) }\end{array}$ & Secondary Criteria & $\begin{array}{l}\text { Importance (Based on } \\
\text { Criteria 2 Evaluation) }\end{array}$ \\
\hline \multirow{3}{*}{ Satisfaction } & \multirow{2}{*}{0.400} & Physical satisfaction & 0.169 \\
& & Psychological satisfaction & 0.387 \\
& & Spiritual satisfaction & 0.443 \\
\hline
\end{tabular}

Of criteria 2 relating to environmental aspects, the safety aspect is considered the most important factor (0.464), followed by conducive (0.281) and unnecessary interaction $(0.255)$, as shown in Table 7 . This shows that respondents feel much safer by working at home in the midst of a pandemic situation that is not over yet.

Table 7. Evaluation of Environmental Criteria

\begin{tabular}{llll}
\hline $\begin{array}{l}\text { Primary } \\
\text { Criteria }\end{array}$ & $\begin{array}{l}\text { Importance (Based on } \\
\text { Criteria 1 Evaluation) }\end{array}$ & Secondary Criteria & $\begin{array}{l}\text { Importance (Based on } \\
\text { Criteria 2 Evaluation) }\end{array}$ \\
\hline \multirow{3}{*}{ Environment } & \multirow{2}{*}{0.249} & conducive & 0.281 \\
& & Safe & 0.464 \\
& & Interaction is not necessary & 0.255 \\
\hline
\end{tabular}

From category 2 related to efficiency aspects, time-saving is considered the most important factor (0.584), followed by cost-saving (0.281), and avoiding traffic jams $(0.135)$, as shown in Table 7. This shows that respondents feel that time is the most important consideration of work from home.

Table 8. Evaluation of Efficiency Criteria

\begin{tabular}{llll}
\hline $\begin{array}{l}\text { Primary } \\
\text { Criteria }\end{array}$ & $\begin{array}{l}\text { Importance (Based on } \\
\text { Criteria 1 Evaluation) }\end{array}$ & Secondary Criteria & $\begin{array}{l}\text { Importance (Based on } \\
\text { Criteria 2 Evaluation) }\end{array}$ \\
\hline \multirow{3}{*}{ Efficiency } & \multirow{2}{*}{0.131} & Saving time & 0.584 \\
& & Save cost & 0.281 \\
& Avoid traffic jams & 0.135 \\
\hline
\end{tabular}

Of criterion 2 relating to productivity aspects, time flexibility $(0.481)$ is the most important factor, followed by venue flexibility $(0.405)$ and arrangement flexibility $(0.114)$, as shown in Table 8 . This underscores the time considerations that respondents consider very important when working from home.

Table 9. Evaluation of Flexibility Criteria

\begin{tabular}{lllc}
\hline $\begin{array}{l}\text { Primary } \\
\text { Criteria }\end{array}$ & Importance (Based on & Secondary Criteria & $\begin{array}{l}\text { Importance (Based on Criteria } \\
\text { 2 Evaluation) }\end{array}$ \\
\hline \multirow{3}{*}{ Flexibility } & \multirow{2}{*}{0.119} & Place flexibility & 0.405 \\
& & Time flexibility & 0.481 \\
& Setting flexibility & 0.114 \\
\hline
\end{tabular}

From criterion 2 related to the productivity aspect, skill development $(0.701)$ is the most important factor, followed by increasing independence $(0.202)$ and increasing productivity (0.097), as shown in Table 9. In respondents' opinion, it can seen that skills development perceived is the most important factor and is felt by respondents when working from home.

Table 10. Evaluation of Productivity Criteria

\begin{tabular}{llll}
\hline $\begin{array}{l}\text { Primary } \\
\text { Criteria }\end{array}$ & Importance (Based on & Secondary Criteria & $\begin{array}{l}\text { Importance (Based on } \\
\text { Criteria 2 Evaluation) }\end{array}$ \\
\hline \multirow{3}{*}{ Productivity } & \multirow{2}{*}{0.102} & Productivity increases & 0.097 \\
& & Skill development & 0.701 \\
& & Increase independence & 0.202 \\
\hline
\end{tabular}


When all elements of criterion 2 were weighted and compared together, skill development (0.701) was the most important factor, followed by time-saving (0.584) and time flexibility (0.481) (Table 10). These factors illustrate the perceived skill development when working from home, as well as the time factor, which is also the top second and third priority. At the same time, survey respondents also recognized security, spiritual and psychological satisfaction as important priorities in the framework of working from home. Another finding is the productivity factor which is actually the factor with the lowest priority.

From this, it can be concluded that employees do not feel increased productivity when working at home, and from their perspective, increasing productivity in the midst of a pandemic situation is not a priority.

Table 11. Priority Rankings Of Tier 2 Evaluation Criteria

\begin{tabular}{lll}
\hline Secondary Criteria & Weight Value & Priority \\
\hline Skill development & 0,701 & 1 \\
Saving time & 0,584 & 2 \\
Time flexibility & 0,481 & 3 \\
Safe & 0,464 & 4 \\
Spiritual satisfaction & 0,443 & 5 \\
Place flexibility & 0,405 & 6 \\
Psychological satisfaction & 0,387 & 7 \\
conducive & 0,281 & 8 \\
Save cost & 0,281 & 9 \\
Interaction is not necessary & 0,255 & 10 \\
Increase independence & 0,202 & 11 \\
Physical satisfaction & 0,169 & 12 \\
Avoid traffic jams & 0,135 & 13 \\
Setting flexibility & 0,114 & 14 \\
Productivity increases & 0,097 & 15 \\
\hline
\end{tabular}

The importance of satisfaction criteria is reflected in criterion 2, which places relatively spiritual satisfaction (0.443) and psychological satisfaction (0.387) as important factors in the order of priority. In addition, environmental criteria with safe $(0.464)$ and conducive $(0.281)$ factors are also important. The productivity aspect is criterion 1, which is considered the least important, and this is reflected in criterion 2 of productivity, namely increasing productivity (0.097) which is the lowest priority of all factors. The interesting thing from the results of this study is that there is a very sharp gap in productivity criteria, where skill development $(0.701)$ is the most important factor, while productivity increase $(0.097)$ is the least important factor.

Analyzing the weighted value of criterion 2 reveals some interesting results. Respondents aged 20 years felt that environmental factors $(0.319)$ were more important than satisfaction factors $(0.253)$. This means they are less afraid of the threat of a pandemic than older age who associate working at home with spiritual and psychological satisfaction. For respondents aged 20 years, the safety factor from the environment is a more important choice than satisfaction.

Judging from the respondent's experience factor, respondents with 11-20 years of experience also believe that environmental factors $(0.342)$ are more important than satisfaction $(0.281)$. This is interesting because considering the respondent's work experience is related to age, where when viewed from the age factor, respondents who have a young age also have the same opinion in comparing satisfaction and environmental criteria.

From the above analysis results, the priorities that are considered important stated by the respondents have almost the same results, but there are differences in the detailed factors 
depending on age, gender, education level, experience, and distance from home to work. It is hoped that the results of the lowered priorities will provide an overview of what employees perceive when working from home. However, the determination of priorities during today's pandemic will certainly be different from the results under normal conditions. In a normal situation, it is possible that the priorities for both criteria 1 and criteria 2 will be very different.

So the conditions and situations when working at home will determine the priority factors that are considered important.

\section{Conclussion}

Although work from home activities have long been carried out in developed countries, work from home in Indonesia was implemented suddenly and without adequate preparation and support. This resulted in research on work from home in Indonesia being still not too much and carried out in situations and conditions that are not normal. This study aims to identify the most important considerations in work from home and prioritize these considerations in disaster situations to provide input on the implementation of work from home to be more effective.

The AHP method reflects a layered structure of complex decision-making and can be applied in conditions of uncertainty or where multiple assessment criteria are required. In this study, a questionnaire was used using the AHP methodology to test the criteria for factors related to work from home. Five main criteria and 15 subcategories were identified from the literature review conducted. The results showed that the satisfaction factor was generally considered by most of the respondents as the main factor in working from home. This is followed by environmental factors, efficiency, flexibility, and productivity. In general, the productivity factor does not get a high priority in the implementation of work from home because respondents tend to think that the productivity factor is not too important compared to other factors during the pandemic.

The findings of this study are likely to serve as a road map for the future development of work-from-home policies, particularly in catastrophe scenarios. Furthermore, we expect that our findings will contribute to a more holistic approach to the future development of work-fromhome applications. Continued study and mediation amongst specialists, as well as potential field applications, are all possibilities for future research. For policy implementation in the design and construction phases, more empirical research on the application of work from home will be required.

\section{References}

[1] ILO and OECD, "The impact of the COVID-19 pandemic on jobs and incomes in G20 economies," p. 46, 2020.

[2] A. W. Bartik, M. Bertrand, Z. Cullen, E. L. Glaeser, M. Luca, and C. Stanton, "The impact of COVID-19 on small business outcomes and expectations," Proc. Natl. Acad. Sci., vol. 117, no. 30, pp. 17656 LP - 17666, Jul. 2020, doi: 10.1073/pnas.2006991117.

[3] B. Kim, "Analytic Hierarchy Process (AHP) Analysis Method," Kim's inforamtion: Seoul, Korea, p. 1, 2013, doi: 10.3390/ijerph17082800.

[4] M. Abdullah, C. Dias, D. Muley, and M. Shahin, "Exploring the impacts of COVID-19 on travel behavior and mode preferences," Transp. Res. Interdiscip. Perspect., vol. 8, p. 100255, 2020, doi: https://doi.org/10.1016/j.trip.2020.100255.

[5] K. Prem et al., "The effect of control strategies to reduce social mixing on outcomes of the COVID19 epidemic in Wuhan, China: a modelling study," Lancet Public Heal., vol. 5, no. 5, pp. e261-e270, 
2020, doi: 10.1016/S2468-2667(20)30073-6.

[6] [Y. Zhang and Z. F. Ma, "Impact of the COVID-19 Pandemic on Mental Health and Quality of Life among Local Residents in Liaoning Province, China: A Cross-Sectional Study," International Journal of Environmental Research and Public Health, vol. 17, no. 7. 2020, doi: 10.3390/ijerph17072381.

[7] S. J. Daniel, "Education and the COVID-19 pandemic," Prospects, vol. 49, no. 1, pp. 91-96, 2020, doi: 10.1007/s11125-020-09464-3.

[8] Humas Kemenpan, "Pencegahan Penyebaran Virus Covid-19 dengan Kerja di Rumah bagi ASN," 01-Jan-2020. [Online]. Available: https://menpan.go.id/site/berita-terkini/pencegahan-penyebaranvirus-covid-19-dengan-kerja-di-rumah-bagi-asn.

[9] G. G. Akbar, N. Nurliawati, M. Muchtar, and A. Ramdhani, "Retrospective Analysis of Work From Home for Civil Servants During The Covid- 19 Pandemic," J. Borneo Adm., vol. 17, no. 2, pp. 183204, 2021, doi: 10.24258/jba.v17i2.811.

[10] A. G. Raišiene, V. Rapuano, K. Varkulevičiute, and K. Stachová, "Working from home-Who is happy? A survey of Lithuania's employees during the COVID-19 quarantine period," Sustain., vol. 12, no. 13, 2020, doi: 10.3390/su12135332.

[11] A. Zaenudin, "No Title," Hasil Survei APJII: 64 Persen Penduduk Indonesia Gunakan Internet ilustrasi pemakaian data internet. Getty Images/iStockphoto Oleh: Ahmad Zaenudin - 15 Mei 2019 Hasil survei APJII menunjukkan, pada 2018 sebanyak 64 persen penduduk Indonesia menggunakan in, 2019. [Online]. Available: https://tirto.id/hasil-survei-apjii-64-persen-penduduk-indonesiagunakan-internet-dH4a.

[12] M. F. Flores, "Understanding The Challenges Of Remote Working And It's Impact To Workers," Int. J. Bus. Mark. Manag., vol. 4, no. 11, pp. 40-44, 2019.

[13] R. Rachmawati, U. Choirunnisa, Z. A. Pambagyo, Y. A. Syarafina, and R. A. Ghiffari, "Work from home and the use of ict during the covid-19 pandemic in indonesia and its impact on cities in the future," Sustain., vol. 13, no. 12, pp. 1-17, 2021, doi: 10.3390/su13126760.

[14] K. A. Prabowo, G. Ellenzy, M. C. Wijaya, and Y. P. Kloping, "Impact of Work from Home Policy during the COVID-19 Pandemic on Mental Health and Reproductive Health of Women in Indonesia," Int. J. Sex. Heal., pp. 1-10, Jun. 2021, doi: 10.1080/19317611.2021.1928808.

[15] D. Dara, A. Eliyana, and Hamidah, "The engagement and working satisfaction of millennial lecturers during the covid-19 pandemic: Differences in gender identity perspectives," Syst. Rev. Pharm., vol. 11, no. 10, pp. 438-445, 2020, doi: 10.31838/srp.2020.10.67.

[16] G. Geusan Akbar, D. Kurniadi, and N. Nurliawati, "Content Analysis of Social Media: Public and Government Response to COVID-19 Pandemic in Indonesia," J. Ilmu Sos. dan Ilmu Polit., vol. 25, no. 1, p. 16, 2021, doi: 10.22146/jsp.56488.

[17] A. P. Sutarto, S. Wardaningsih, and W. H. Putri, "Work from home: Indonesian employees' mental well-being and productivity during the COVID-19 pandemic," Int. J. Work. Heal. Manag., vol. 14, no. 4, pp. 386-408, Jan. 2021, doi: 10.1108/IJWHM-08-2020-0152.

[18] D. Yuniarti, D. Rosadi, and Abdurakhman, "Inflation of Indonesia during the COVID-19 pandemic," J. Phys. Conf. Ser., vol. 1821, no. 1, 2021, doi: 10.1088/1742-6596/1821/1/012039.

[19] F. Lubis and A. Yudhi, "Study development of digital teaching materials support online learning during Covid-19," J. Phys. Conf. Ser., 2021, doi: 10.1088/1742-6596/1811/1/012029.

[20] R. W. Saaty, "The analytic hierarchy process - what it is and how it is used," Math. Model., vol. 9, no. 3, pp. 161-176, 1987, doi: https://doi.org/10.1016/0270-0255(87)90473-8.

[21] T. Erden and H. Karaman, "Analysis of earthquake parameters to generate hazard maps by integrating AHP and GIS for Küçükçekmece region," Nat. Hazards Earth Syst. Sci., vol. 12, no. 2, pp. 475-483, 2012, doi: 10.5194/nhess-12-475-2012.

[22] S. . Schilling, "Implementing a successful telecommuting program," Compens. Benefits Manag. Greenvale, Autumn, vol. 15, no. 4, p. 58, Jan. 1999.

[23] A. Gage, " 'Telecommuting: the boss view," Pioneer Planet, Jan. 1998.

[24] Di. E. Bailey and N. B. Kurland, "A review of telework research: findings, new directions, and lessons for the study of modern work," Br. J. Anaesth., vol. 89, no. 5, pp. 707-710, 2002, doi: $10.1093 / \mathrm{bja} / 89.5 .707$. 
[25] C. . Cooper and N. B. Kurland, "Telecommuting, professional isolation, and employee development in public and private organizations," J. Occup. Environ. Med., vol. 36, no. 9, pp. 983-988, 2002.

[26] Y. Song, K.-W.; Lee, "Re-scaling for Improving the Consistency of the AHP Method," Soc. Sci. Res, vol. 29, no. 4. Emerald Publishing Limited, pp. 271-288, 01-Jan-2013. 